\title{
The Influence of Drainage Devices and Post-Bog Soil Changes on Water Retention in Drained Lower Supraśl River
}

\author{
Aleksander Kiryluk ${ }^{1}$ \\ 1 Faculty of Civil and Environmental Technology, Bialystok University of Technology, ul. Wiejska 45E, 15-351 \\ Bialystok, Poland \\ e-mail: a.kiryluk@pb.edu.pl
}

\begin{abstract}
Water shortages occurring in the natural environment are the result of progressing climate changes, including the decreasing amount of atmospheric precipitation. In Poland, during the vegetation periods, droughts occur every 4-5 years, which causes losses in the field production and in forest communities. Reducing the negative effects of drought is possible by retention of water within a catchment. This method of improving the water balance has been included in the provisions of the Water Framework Directive and Water Law. On the meliorated valley objects, there are melioration devices that enable regulation of the moisture content, including irrigation during periods of drought. Drainage ditches can also retain water in the early spring periods with high flows in rivers. The studies carried out on the Lower Supraśl river site showed that about $40 \%$ of drainage devices used for water damming (dams and ramps), as well as for water distribution (feeders and detailed ditches) are not technically efficient and do not fulfil the function of moisture content regulation. Fibrous-muck soils occurring on this object, due to the lack of rainfall and irrigation, reduced the water retention capacity by approximately $30 \%$. Modernization and reconstruction of drainage devices on valley objects will enable increasing the retention within individual catchments.
\end{abstract}

Keywords: soil drought, retention of water, drainage devices, post-bog soil, irrigation.

\section{INTRODUCTION}

\section{Problems of water shortages and retention in the environment}

Progressively occurring climate changes (also observed and recorded in Poland) cause, among others, reduction of rainfall and increased field evaporation, i.e. formation of a negative water balance. The value of the climatic water balance (CWB), calculated as the difference between potential evapotranspiration and average annual precipitation $(\mathrm{CWB}=\mathrm{ETP}-\mathrm{P})$ [Doroszewski et al. 2008], amounts for the Podlasie province to $70 \mathrm{~mm}$, on average, while during the vegetative periods (April - September), the value of CWB is even 139-241 mm [Kiryluk 2007]. The higher the CWB value, the greater the shortage of water in the environment. During the growing seasons, hydrological droughts and soil droughts occur every few (4-5 years) years (the groundwater level decreases by more than $50 \mathrm{~cm}$ in relation to the optimal levels and is arranged at a depth often below $1 \mathrm{~m}$ ) (Figure 1).

Under the soil drought conditions, there is a need to retain water in the catchment area. This can be accomplished through natural methods: afforestation, restoration of drained wetlands, proper agro-technology and tillage, increasing the soil retention by mulching. In some catchment areas, improvement of the water balance by natural methods is not possible or ineffective. In such catchments, it is necessary to maintain efficient melioration devices improving the water balance. The current important task of water management in Poland is the reconstruction of water retention in catchments of small watercourses and in the agricultural landscape, both through the construction of artificial retention reservoirs, as well as the reconstruction (reclamation) of small 


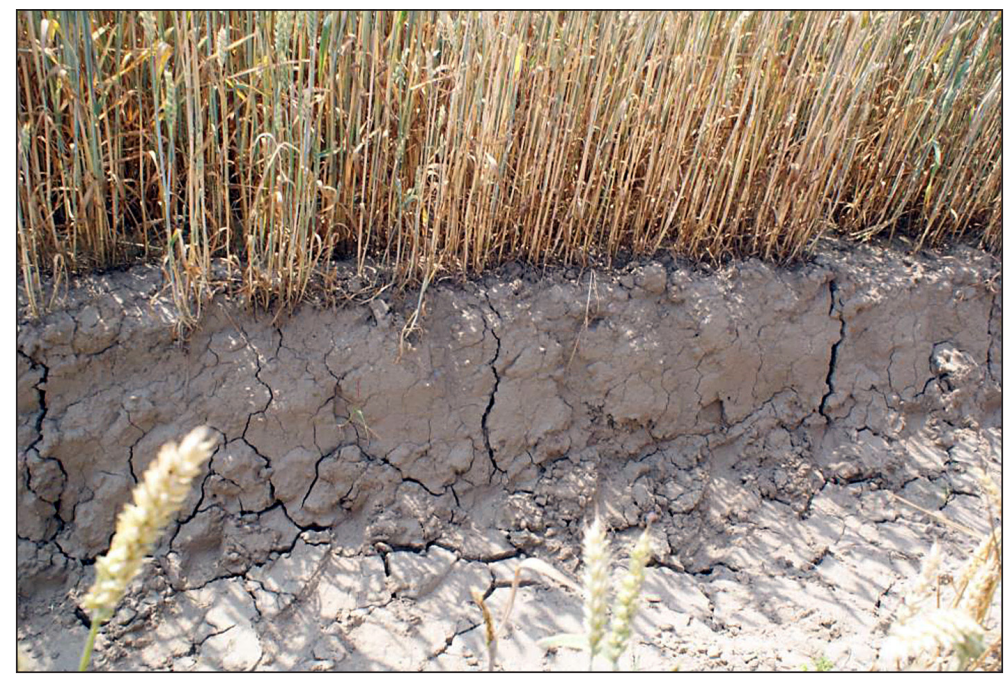

Figure 1. Soil drought on cultivated fields in the village of Nowokornino, Podlaskie Province - July 2015 (photo A. Kiryluk)

rural reservoirs and ponds. An important role can also be played by controlling soil retention in the valleys of small lowland rivers by means of an adjustable outflow on the built weirs during the irrigation works [Kędziora et al. 2014]. The criticism of the drainage impact on natural environment observed in recent years in Poland (on the basis of individual errors occurring at intensive drainage) should not reduce the formal and financial activities limiting the development of this important water infrastructure in rural areas [Gromiec 2012]. The need to increase the retention of irrigation also results from the structural and technological changes in the Polish agriculture over the last few decades. The process of reducing retention in catchments has been taking place for a long time. The intensification of agriculture and the progressive drainage caused the disappearance of, among others, $60 \%$ of water reservoirs with an area smaller than 1 ha (ponds) in the last 200 years. The beginnings of irrigation works in Poland were recorded already in the 19th century. In the years 1815-1918, most of the work was done in Kongresówka, in then Poznańskie, in Pomerania and in Silesia. Another revival of irrigation works took place in the interwar period. The largest number of melioration works of mainly drainage character was made in 1960-1980, when several thousand hectares of agricultural land was drained annually in the Podlasie province. Since 1991, regressions of land drainage have been observed due to poor profitability of agricultural production and as a result of protests of environmentalists [Lipiński 2006]. During some drainage works, the naturalness of rivers and watercourses was lost due to accelerated outflow of large waters, deforestation and embankment of rivers, their excessive regulation and elimination of landscape retention [Żelazo 2006].

In the last decades of the 20th century and in the 21 st century, the increasing occurrence of extreme phenomena related to water in the environment has been observed (Figure 2). Droughts and floods occurring in various places and at different times on the globe should be considered as natural phenomena.

The water resources on the globe are constant, the states of water concentration change and the water vapour moves to various places in the atmosphere [Mioduszewski 2017]. In the natural environment, especially in agricultural areas, it is important to assess the resources and availability of water in a specific area. The assessment of changes in resources is most often carried out in the area of a given catchment. Shaping the water resources in the catchment depends mainly on the size of precipitation, but also on the retention capacity in its area and size of the outflow.

The Water Framework Directive [2000] and the new Water Law [2017] in Poland define important and urgent tasks in the field of improving the water management due to the natural environment and agriculture. Among many new tasks and technical solutions for agricultural areas, the most important ones are:

- the use of technical and non-technical methods for retention of water with its simultaneous discharge from urbanized areas;

- in order to increase the soil retention capacity, appropriate agrotechnical methods should be 


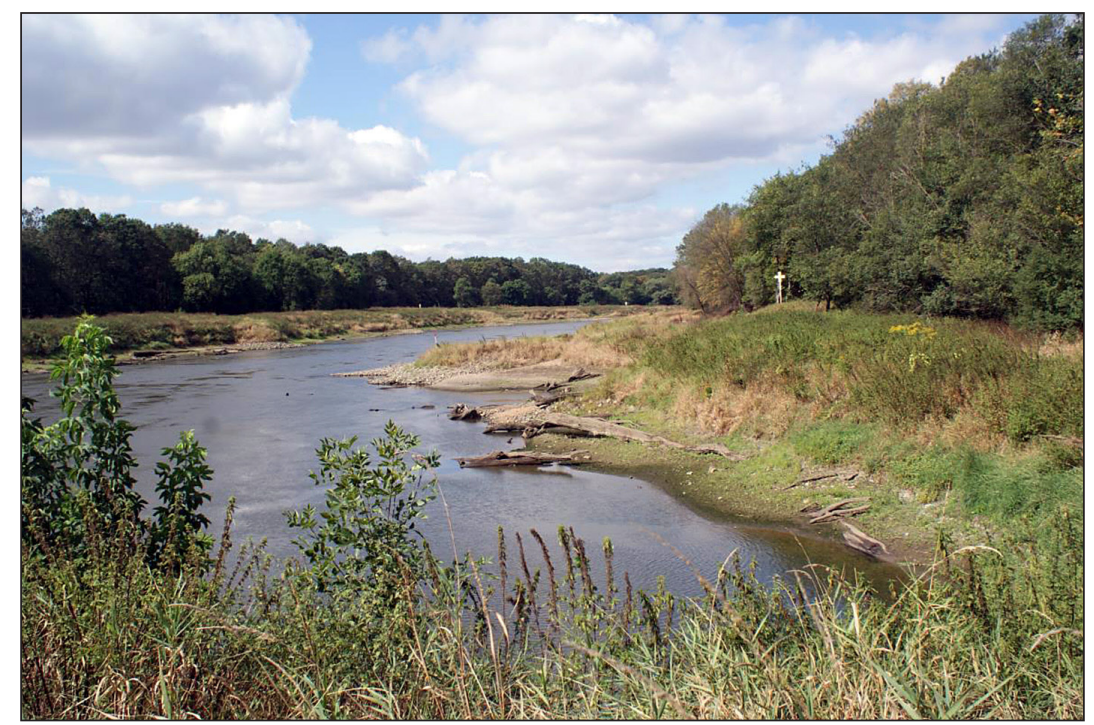

Figure 2. Hydrological drought on the Oder - September 2015 (photo A. Kiryluk)

applied, including increasing the organic matter content;

- introducing the plant species suitable for the existing water conditions (Climatic Water Balance) and characterized by low transpiration coefficient;

- reconstruction and modernization of the existing drainage systems in accordance with the water needs of a given catchment area;

- manufacturing technical devices to stop water drainage and creating so-called closed circuits.

The paper analyses and evaluates the impact of irrigation devices and meliorated post-bog soils on the water retention value on the valley object of Lower Supraśl river in the aspect of a long-term research.

\section{Current legal conditions for agricultural melioration and drainage devices}

The basic task of the melioration is to optimize the system of yield-forming factors in the environment (water, air, temperature, light, nutrients) throughout the plant development period to increase agricultural production, improve and shape the habitat, protect, shape as well as reproduce the water resources. Land drainage includes the measures improving the soil production capacity, facilitating its cultivation and protecting the agricultural land against floods [Water Law 2017]. The current legal provisions deviate from the classification of melioration devices as basic and detailed. Under the current legal status, pursuant to art. 197 of Water Law, water drainage devices are: ditches together with structures functionally related to them, drainage networks, pipelines, pump stations used exclusively for agricultural purposes, fish ponds, dikes in irrigated areas, gravity irrigation systems and pressure irrigation systems, if they are used for regulation of water relations to improve the soil production capacity and facilitate its cultivation. Provisions regarding water melioration devices are also applied to the structures stopping the water erosion, access roads necessary for the use of drainage areas, phyto-melioration and agro-melioration, anti-erosion systems, management of drained permanent meadows or pastures, management of wasteland for permanent meadows or pastures. However, the rules for financing the construction, operation and maintenance costs of these devices have not been clearly defined.

According to art. 199 of the Act, the responsibility of implementation of water melioration devices is upon the owners of the land. Water melioration devices can be constructed at the expense of the Treasury, including the participation of EU Community funds. In such a situation, the interested landowners, to whom these devices exert a beneficial influence, pay back some of the costs of implementing these devices in the form of a drainage charge. In reference to the new Water Law, the state body (Polish Waters) was established, the main task of which is the overall management and supervision of water management in the country [Position of the Polish Waters ...]. The costs of producing the drainage devices and their maintenance can be an unbridgeable barrier for many users (small and medium farms). 
The issues of water management in rural areas and agricultural drainage have been minimized and marginalized in the new legislation. Leaving almost complete responsibility for the technical condition and functioning of drainage devices on users of the drained areas can cause large losses in the devices and diminish the positive effects of drainage. Non-functioning drainage and irrigation ditches are often the cause of excessive moisture content or mudding, and may also cause excessive dehydration and drainage of the area. The lack of flow and adequate oxygenation of water in ditches and watercourses can cause excessive eutrophication and reduction of biological life [Kiryluk 2014].

\section{Study area and methodology}

Lower Supraśl object has an area of 1505 ha. It is situated in the valley part of the Supraśl river (in $\mathrm{km} 0+000$ to 29+400) [Figure 3]. As a result of irrigation works on this object in 1971-1977, the existing main ditches were reconstructed, and a network of new ditches with drainage and irrigation functions was constructed. Currently, there are $125.6 \mathrm{~km}$ of drainage and irrigation ditches, 90 valves and culverts damming water, and 238 melioration culverts (Table 1). Due to specific location, the object can fulfil many functions. For many years, these were high-production meadows and pastures. The changes in agriculture have reduced these basic production functions. Short distance from Białystok agglomeration allows the use of other environmentally abundant recreational and leisure functions of the river valley. The basic condition for using all the functions of this object is to maintain proper moisture content, including retention of rainwater and the surface waters flowing in the Supraśl river, by means of various methods and technical solutions. The object is characterized by a strongly developed network of drainage ditches (Figure 2), which hinders its economic use in the current mechanization of the field works.

\section{The scope of research}

In order to assess the technical condition of the irrigation devices and determine the total water retention at the site, the following field and chamber works were carried out:

- inventory of soils on the site and determination of their physical properties,

- device cataloguing,

- calculation of water retention in drainage ditches,

- calculation of water retention in variously transformed post-bog soils.

On the basis of the data above, the calculation of the water balance in the natural environment,

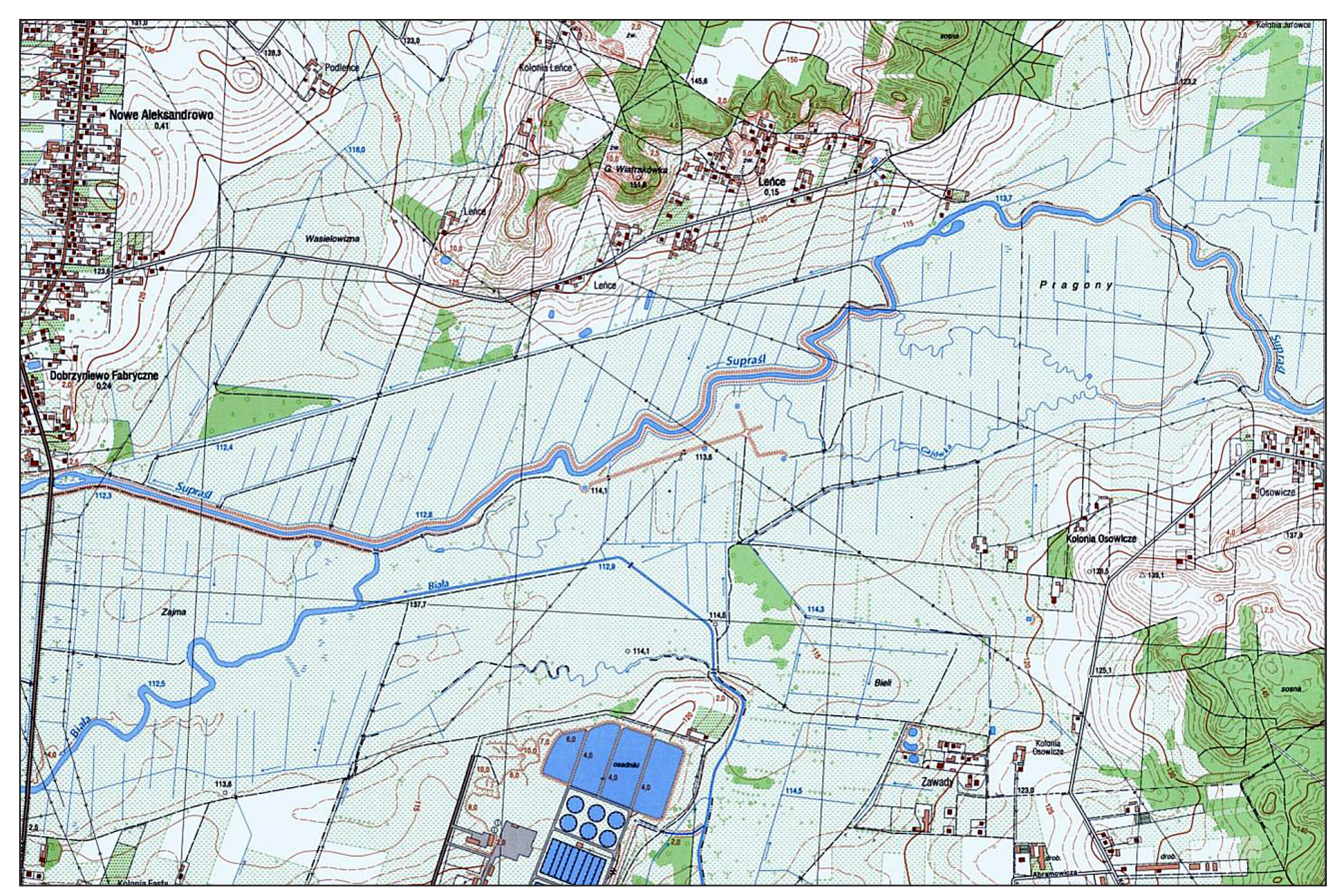

Figure 3. Lower Supraśl river valley in km: 7+500 do 15+300. Source: own study based on GUGiK topographic map Nowe Aleksandrowo N-34-107-A-c-4 
Table 1. Melioration devices on Lower Supraśl river object - quantitative and technical state

\begin{tabular}{|c|c|c|c|c|c|}
\hline \multirow[b]{2}{*}{ Melioration device } & \multirow[b]{2}{*}{ Unit } & \multirow[b]{2}{*}{ Quantity } & \multicolumn{3}{|c|}{ Efficiency and functionality (\%) } \\
\hline & & & fully functional & partly functional & $\begin{array}{l}\text { not fulfilling the } \\
\text { function }\end{array}$ \\
\hline Total drainage ditches & $\mathrm{m}$ & 125634 & 60 & 10 & 30 \\
\hline Flaps and throttles & pcs. & 90 & 50 & 10 & 40 \\
\hline Melioration culverts & pcs.. & 238 & 70 & 10 & 20 \\
\hline Drainage networks & ha & 245 & 90 & 5 & 5 \\
\hline Drainage wells & pcs. & 38 & 85 & 10 & 5 \\
\hline Drainage outlets & pcs. & 110 & 85 & 10 & 5 \\
\hline Dikes in irrigated areas & $\mathrm{m}$ & 4080 & 95 & 5 & \\
\hline Surface of the object & ha & 1505 & & & \\
\hline
\end{tabular}

including biomass production was carried out. The field studies were conducted in 1982-2015.

\section{Research methodology}

For the location of devices in the field, melioration maps in the 1:2000 scale, project assumptions regarding the drainage structures and post-construction surveys, and equipment register [Records book ...] of the Lower Supraśl river drainage project, were used. These materials were utilized to accurately locate the linear and point melioration devices for measurements. Direct field measurements and assessment of technical parameters affecting the efficiency and functionality of devices were performed in 2015-2016 (Table 1, Table 2). The assessment of the technical condition was carried out according to the methodology of Kaca and Interewicz [1991]. Water retention values in the drainage ditches (Table 3 ) were calculated by assuming a ditch volume minus $20 \%$. The retention time in ditches was calculated based on the water supply in the amount of $30 \%$ SSQ (average water mean). Leaving $70 \%$ of the flow in the river should provide the conditions for biological life and maintenance of river self-purification processes. The amount of water intake for irrigation in the amount of $30 \%$ of SSQ flow is $2.08 \mathrm{~m}^{3} \cdot \mathrm{s}^{-1}$.

\section{RESULTS AND DISCUSSION}

\section{Melioration devices - their impact on water retention on the object}

The Lower Supraśl object has a strongly developed network of drainage ditches in a systematic order (Figure 4). It is characteristic network system and is most often used in melioration of objects in the lower sections of the watercourse.

The main problem in the effective regulation of the moisture content conditions on the research object is the inadequate technical condition of drainage ditches. A large part of ditches (40\%) does not fulfil their functions (Table 1). There are many reasons for the deterioration of technical condition. In addition to the human factor, natural subsidence of peat bogs causes shallowing of ditches, eliminating normative falls in the bottom. The average annual rate of decline of the low peat bog area surface on the Solec object was 1.7-2.6 cm year $^{-1}$ [Oleszczuk et al. 2017].

The most appropriate time of water retention in drainage ditches is the early spring period with great water flows (WWQ). Within an hour, at the SSQ flow of $6.93 \mathrm{~m}^{3} \cdot \mathrm{s}^{-1}$ in Supraśl river (Nowe Aleksandrowo weir), there are $24948 \mathrm{~m}^{-3}$ water available. The permissible $30 \%$ water uptake from mean SSQ flow on weirs will not cause

Table 2. Technical state of drainage ditches

\begin{tabular}{|c|c|c|c|c|c|c|c|c|c|}
\hline \multirow{3}{*}{$\begin{array}{l}\text { Type of } \\
\text { device }\end{array}$} & \multirow{3}{*}{$\begin{array}{l}\text { Length } \\
\text { (m) }\end{array}$} & \multicolumn{8}{|c|}{ Technical parameters of ditches ( $\%$ of the quantitative status) } \\
\hline & & \multicolumn{2}{|c|}{ ditch depth $[\mathrm{cm}]$} & \multicolumn{3}{|c|}{ Inclination in the bottom (\%o) } & \multicolumn{3}{|c|}{ Mud at the bottom $(\mathrm{cm})$} \\
\hline & & $<80$ & $80-130$ & $\begin{array}{c}\text { No } \\
\text { inclination }\end{array}$ & $<5$ & $>5$ & $<10$ & $10-30$ & $>30$ \\
\hline Main ditches & 30540 & 15 & 85 & 5 & 65 & 30 & 60 & 20 & 20 \\
\hline $\begin{array}{l}\text { Detailed } \\
\text { ditches }\end{array}$ & 95094 & 65 & 35 & 35 & 55 & 10 & 35 & 35 & 30 \\
\hline
\end{tabular}




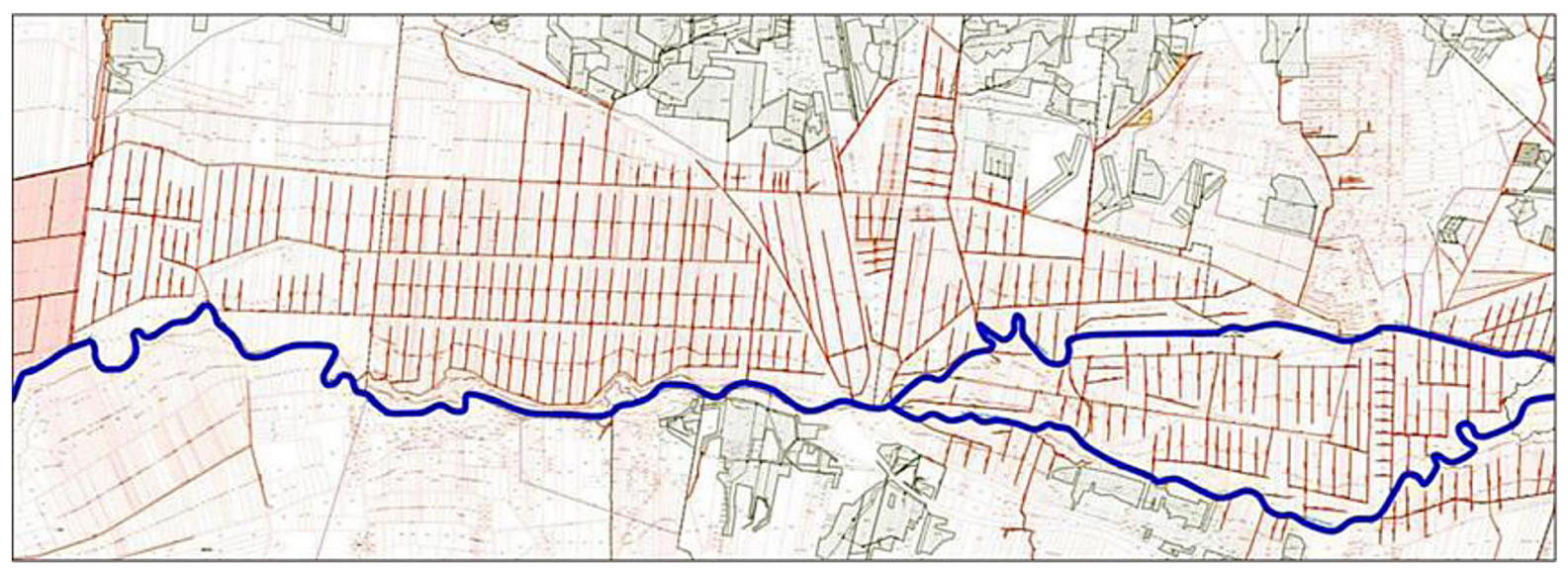

Figure 4. Supraśl river and network of melioration ditches on the object.

Source: own study based on Geomelio.

disruption of flows in the river and will not affect the biological flow. Often, the uptake of water for agricultural irrigation from current flows in the river is used by environmentalists as a threat to the naturalness of rivers. The calculated filling time is 18.5 hours (Table 3 ) is realistic, while maintaining the normative parameters in ditches (proper inclinations, hydraulic cross-sections) and on damming valves. In practice, due to the inefficiency of the valves and the lack of slope in the ditches (Table 2), the water filling time may be several times longer and last up to a week.

Water retention in the post-bog soil profile

According to the Systematics of Polish Soils [2011], the predominant area of the tested object is the fibrous-muck organic soil: Order 10. Organic soils (O) Histosols, Type 10.6. Organic muck soil (OM) murshic histosols, Subtype 10.6.1. Fibrousmuck soil (OMi) Murshic Endofibric Histosol.

The percentage of soils with different peat deposit is shown in Table 4. The soils with high peat deposit occur on $31.5 \%$ of the surface of the study object.

The basic task of the drainage technique on the object is balancing the water in the soil profile. The soil retention capacity plays an important role here. Water resources in the soil can be large. This occurs in alluvial and loess soils, which can hold $350-450 \mathrm{~mm}$ of water in a 1-meter layer (3.5-4.5 thousand $\mathrm{m}^{3} / \mathrm{ha}$ ). The degree of rainwater availability in structural soils is high (up to $85 \%$ ), and in the soils with improper agrotechnics and over-dried ones, it decreases and even the availability decreases up to $20 \%$ [Bieniek et al. 2003; Ostrowski 2011]. Low bogs, remaining in a nonhydrated state, usually fluvogenic, have high water retention capacity due to the high peat porosity (up to $85 \%$ vol.). This property is reduced by up to $30 \%$ due to excessive dehydration of peat bogs as a result of drainage works. Intensive drainage and agricultural management of peat bogs began in Poland in the 18th century, but the largest areas

Table 3. Technical parameters and ditch filling options at medium water flow in Supraśl river

\begin{tabular}{|c|c|c|c|c|}
\hline \multirow[b]{2}{*}{$\begin{array}{l}\text { Name of the } \\
\text { melioration device }\end{array}$} & \multicolumn{2}{|c|}{ Technical parameters of devices } & \multicolumn{2}{|c|}{ Retention possibilities of melioration devices } \\
\hline & $\begin{array}{l}\text { Ditch length on } \\
\text { the object }(m)\end{array}$ & $\begin{array}{l}\text { Cross-sectional area } \\
\text { of the ditch }\left(\mathrm{m}^{-2}\right)\end{array}$ & $\begin{array}{c}\text { Volume of retained water at } \\
80 \% \text { ditch filling }\left(\mathrm{m}^{-3}\right)\end{array}$ & $\begin{array}{l}\text { Ditch filling time (when } \\
\text { collecting water in the } \\
\text { amount of } 2.08 \mathrm{~m}^{3} \cdot \mathrm{s}^{-1}(30 \% \\
\mathrm{SSQ})^{*}(\mathrm{~h})\end{array}$ \\
\hline $\begin{array}{l}\text { Main deep } \\
\text { ditches }(100-130 \mathrm{~cm})\end{array}$ & 30540 & 1.55 & 37870 & 7.0 \\
\hline $\begin{array}{l}\text { Detailed medium } \\
\text { depth ditches } \\
(70-100 \mathrm{~cm})\end{array}$ & 42750 & 1.05 & 35910 & 5.8 \\
\hline \multirow[t]{2}{*}{$\begin{array}{l}\text { Detailed shallow } \\
\text { ditches }<70 \mathrm{~cm}\end{array}$} & 52344 & 0.75 & 31406 & 5.7 \\
\hline & 125634 & & 105186 & 18.5 \\
\hline
\end{tabular}

* SSQ flow for the Supraśl river in Nowodworce $-6.93 \mathrm{~m}^{3} \cdot \mathrm{s}^{-1}$, Source: own study

Own study based on: Hydrological Operate for Białystok Voivodeship, part 1. Controlled cross-sections (Supraśl river 1992) IMGW Białystok. 
Table 4. The area and deposit of post-bog soils (muck soil and mucky soils) on the Supraśl Dolna object

\begin{tabular}{|l|c|c|c|}
\hline \multicolumn{1}{|c|}{ Deposit of soils } & $\begin{array}{c}\text { Deposit. } \\
\mathrm{cm}\end{array}$ & Area. ha & Share. \% \\
\hline Shallow soils & $30-80$ & 552 & 36.7 \\
\hline $\begin{array}{l}\text { Average depth } \\
\text { soils }\end{array}$ & $80-130$ & 478 & 31.8 \\
\hline Depth soils & $>130$ & 475 & 31.5 \\
\hline Total & & 1505 & 100.0 \\
\hline
\end{tabular}

of peatlands were drained in the second half of the 20th century. These works resulted in a large reduction of water resources in peatlands [Ilnicki 2002, Kiryluk 2007].

In order to determine the potential water retention on the object, the following materials were used: soil inventories and their physical water properties tested [Kiryluk 2017]. On the basis of this data, the amount of potentially water retention in the fibrous-muck soils was calculated. The most retained water was found in peat soils with a deep profile and low degree of damage. Smaller amounts of collected water were found in the soils of medium and shallow peat deposit and significant transformation of peat mass (Table 5).

The peat bogs with a low degree of mucking (Mt I) accumulate up to $85 \%$ of water in their volume. The size of retention of valley objects equipped with drainage devices depends on the technical condition and functionality of drainage devices. The research carried out on the Lower Supraśl object showed that about $40 \%$ of the facilities are not technically efficient. This will prevent the retention of water spreading around the site and carrying out the hydration, distribution and retention of water in water irrigation systems. Shallowing up to $70 \mathrm{~cm}$ deep ditches, the disappearance of longitudinal falls occurs on many drained low peats, among others, on Solec peat bog with an area of 220 ha in the Masovian province [Oleszczuk et al. 2017].

The performed water balance for the average hydrological year on the site (Table 6) showed that for the production of plant biomass at the level of $37 \mathrm{Mg} \cdot \mathrm{ha}^{-1}$ green mass (yield obtained from various species and plant communities), about $67.9 \%$ of water necessary in the evapotranspiration process is missing in this ecosystem. The main mass of the restored water (over 90\%) on the object occurs in the soil profile. Water shortages occur quite frequently on many drained objects with inefficient linear and point melioration devices. The lack of irrigation on these objects leads successively to the degradation of the soil environment and multispecies phytocoenoses [Kiryluk 2007]. In the Podlasie province, a multi-annual irrigation program was developed [Regional program ... 2007] which, however, has not been implemented for many reasons. In the years 2000-2011, the area irrigated with various techniques decreased in Poland by $35.8 \%$ and covered only 66.5 thousand ha of arable lands [Kłos 2013], and the downward trend of irrigated areas is still observed.

\section{CONCLUSIONS}

1. On the meliorated Lower Supraśl object with 1505 ha area, it was found that $40 \%$ of drainage ditches are technically inefficient due to silting and lack of bottom slopes, lower river cross-section, shallowing and silting of ditches in post-bog habitats, which prevents irrigation.

2. The process of mucking and the increase in the occurrence of Mt III soil causes a reduction in the retention capacity of these soils. The poorly mucked soils (Mt I) retained $953 \mathrm{~mm}$ of water, while the strongly mucked soils (Mt II) retained only $544 \mathrm{~mm}$ of water.

Table 5. Physical and water properties and water retention in variously transformed post-bog soils

\begin{tabular}{|c|c|c|c|c|c|}
\hline $\begin{array}{l}\text { Type of post-bog soils, degree of } \\
\text { transformation, deposit }\end{array}$ & $\begin{array}{l}\text { Soil surface } \\
\text { (ha) }\end{array}$ & $\begin{array}{l}\text { Volume of peat- } \\
\text { muck soils }\left(\mathrm{m}^{3}\right)\end{array}$ & $\begin{array}{c}\text { Full water } \\
\text { capacity (\% vol.) }\end{array}$ & $\begin{array}{l}\text { Volume of retained } \\
\text { water }\left(\mathrm{m}^{-3}\right)\end{array}$ & $\begin{array}{l}\text { Water retention } \\
\text { in post-bog soil } \\
\text { profile }(\mathrm{mm})^{*}\end{array}$ \\
\hline $\begin{array}{l}\text { Shallow peat in the degree of } \\
\text { mucking Mt III, peat deposit } \\
30-80 \mathrm{~cm} \text {. medium deposit, } \\
\text { depth } 65 \mathrm{~cm}\end{array}$ & 475 & 3087500 & 83.7 & 2584236 & 544 \\
\hline $\begin{array}{l}\text { Medium-deep peat in degree } \\
\text { of mucking Mt I, peat deposit } \\
80-130 \mathrm{~cm} \text {, average depth } 90 \mathrm{~cm}\end{array}$ & 478 & 4302000 & 85.4 & 3673908 & 786 \\
\hline $\begin{array}{l}\text { Deep peat, degree of mucking Mt } \\
\text { l, peat deposit }>130 \mathrm{~cm} \text {, average } \\
\text { depth } 110 \mathrm{~cm}\end{array}$ & 552 & 88.4 & 86.6 & 5258352 & 953 \\
\hline
\end{tabular}

* $10 \mathrm{~m}^{3}$ water per $1 \mathrm{ha}=1 \mathrm{~mm}$ rainfall water. 
Table 6. Water balance on the Lower Supraśl object

\begin{tabular}{|c|c|c|c|}
\hline Items & Balance element & Unit & Quantity \\
\hline 1 & $\begin{array}{l}\text { Water retention in drainage ditches at normative } \\
\text { parameters }\end{array}$ & $m^{-3}$ & 105186 \\
\hline 2 & Water retention in the soil profile & $m^{-3}$ & 11501060 \\
\hline 3 & The sum of the retained water (ditches + soil) & $m-3$ & 11606246 \\
\hline 4 & $\begin{array}{l}\text { Production of plant biomass from the area at a yield of } \\
35 \mathrm{t} \cdot \mathrm{ha}^{-1} \text { green forage }\end{array}$ & $\mathrm{Mg}(\mathrm{t})$ of green forage & 55685 \\
\hline 5 & Transpiration coefficient & $\mathrm{X}$ & 650 \\
\hline 6 & $\begin{array}{l}\text { Water consumption for biomass production (total } \\
\text { evapotranspiration) }\end{array}$ & $m^{-3}$ & 36195250 \\
\hline 7 & Balance result (items 3-6) & $\mathrm{m}^{-3}$ & -24589004 \\
\hline 8 & $\begin{array}{l}\text { satisfying the needs of aquatic plant communities on } \\
\text { the object }\end{array}$ & $\%$ & 32.1 \\
\hline
\end{tabular}

3. As a result of the lack of technically efficient drainage system, the calculated water balance showed significant water shortages causing a reduction in the economic and non-production functions of the valley object. The use of meadow and environmental functions of the Lower Supraśl object requires maintenance of irrigation and drainage devices.

4. There is an urgent need to refine legal, organizational and financial regulations regarding the maintenance and reconstruction of detailed drainage systems.

\section{Acknowledgements}

The study was conducted as a research project WZ/WBiIŚ/8/2019 in Faculty of Building and Environmental Engineering and financed by Ministry of Science and Higher Education.

\section{REFERENCES}

1. Bieniek B.,Helińska A.,Bieniek A. 2003. Changes in retention properties of muck soils used in various ways [in Polish]. Zesz. Probl. Post. Nauk Rol. z. 493.cz.III, 571-578.

2. Doroszewski A., Kozyra J.,Pudełko R.,Stuczyński T., Jadczyszyn J., Koza P., Łopatka A. 2008. Monitoring of agricultural drought in Poland [in Polish]. Wiad. Melior.i Łakars. nr 1(416), 35-38.

3. Directive 2000/60/EC of the European Parliament and of the Council of 23 October 2000 establishing a framework for Community action in the field of water policy (Dz.U.UE L of 22 December 2000.

4. Gromiec M.2012. Water shortages associated with droughts - legal-economic and socio-economic aspects [in Polish]. Wiad. Mel. i Łąk. nr 1(432),16-17.

5. Ilnicki P.2002. Peat and peat bogs [in Polish]. Wyd. AR Poznan, pp. 606.
6. Kaca E., Interewicz A. 1991. Methodology for the assessment of the technical condition of irrigation devices in irrigation systems [in Polish]. Mat. Konf. Nauk. "Postęp w projektowaniu i eksploatacji systemów nawodnień podsiąkowych". Warszawa: Wyd. SGGW, 90-99.

7. Kasperek R, Wiatkowski M. 2008. Evaluation of the effectiveness of drainage ditches in agricultural areas [in Polish]. Zesz. Probl.Post. Nauk Roln. z. 528, 213-222

8. Kędziora A., Kępińska-Kasprzak M., Kowalczak P., Kundzewicz Z., Miler A., Pierzgalski E., TokarczykT.2014. Threats related to water scarcity [in Polish]. Nauka 1/2014, 149-172.

9. Kiryluk A. 2014. Melioration devices and their role in eco-engineering and environmental protection of agricultural areas in the Podlasie province [in Polish]. Inżynieria Ekologiczna, vol. 40, 33-43.

10. Kiryluk A. 2017.Changes of the physical-waters properties of murshic endofibric histosols in the aspect of long-term investigation on the drainage object Supraśl Dolna. Journal of Ecological Engineering, volume 18, Issue 5, Sep. 2017, pages 90-95 DOI: 10.12911/22998993/7461

11. Kiryluk A., 2007. Changes in post-bog habitats and phytocoenoses in the Supraśl valley [in Polish]. Woda-Środow. Obsz. Wiejs. Rozpr. nauk. i monogr. Nr 20. Wyd. IMUZ Falenty, pp. 146.

12. Kłos L.2013. The condition and functioning of water melioration devices in rural areas [in Polish]. Ekonomia i Środowisko 3(46), 196-206.

13. Records book of water, devices and meliorated lands. WZMiUW in Bialystok (currently Polish Waters)

14. Lipiński J. 2006. Outline of development and production and environmental importance of drainage in the light of research [in Polish]. Acta Sci. Pol., Formatio Circumiectus, 5(1), 3-15

15. Mioduszewski W.2017. Natural methods of reducing the effects of drought and flood threats [in Polish]. Wiadomości Melioracyjne i Łąkarskie 
2//2017, 69-72.

16. Oleszczuk R., Gąsowska M., Guz G., Urbański J., Hewelke E.2017. Impact of settlement processes and disappearance of organic muck soils on longitudinal profiles of drainage and irrigation ditches [in Polish]. Acta Sci. Pol. Formatio Circumiectus. DOI: http://dx.doi.org/10.15576/ASP. FC/2017.16.3.3www.formatiocircumiectus.actapol.net/pl

17. Ostrowski K. 2011. The role of detailed melioration equipment in agriculture and natural environment [in Polish]. Wiad. Mel. i Łąk. nr 54(4), 155-160.

18. Water Law, Act of July 20, 2017. Dziennik Ustaw 2017 poz. 1566 .
19. Regional operational program of irrigation of the Podlasie province for the years 2007-2013. WZMiUW (Polish Waters) in Bialystok, 2007, typescript [in Polish], pp. 74

20. Position of the Polish Waters in the matter of maintaining detailed drainage devices https://sites. google.com/site/melioracjerolneilesne/home/melioracje-w-Polsce

21. Systematics of Polish Soils. 2011. Soil Science Annual (Roczniki Gleboznawcze) 62, 3, 5-142. (in Polish)

22. Żelazo J.2006. Renovation of rivers and valleys. Infrastructure and ecology of rural areas [in Polish]. nr 4.PAN O/Kraków, nr 4/1/2006, 11-31 